\title{
First autochthonous Dirofilaria immitis (Leidy, 1856) infection in a dog in Hungary
}

\author{
O. JACSÓ ${ }^{1}$, M. MÁNDOKI ${ }^{2}$, G. MAJOROS ${ }^{1}$, M. PÉTSCH${ }^{3}$, M. MORTARINO $^{4}$, \\ C. $\mathrm{GENCHI}^{4}$, É. FOK ${ }^{1}$
}

\begin{abstract}
${ }^{1}$ Szent István University, Faculty of Veterinary Science, Department of Parasitology and Zoology, Budapest, Hungary, E-mail:fok.eva@aotk.szie.hu; ${ }^{2}$ Szent István University, Faculty of Veterinary Science, Department of Pathology and Forensic Veterinary Medicine, Budapest, Hungary; ${ }^{3}$ Szent István University, Faculty of Veterinary Science, Department and Clinic of Internal Medicine, Budapest, Hungary; ${ }^{4}$ Department of Pathology and Parasitology, Faculty of Veterinary Science, University of Milan, Italy
\end{abstract}

\begin{abstract}
Summary
A 4 year-old, male Hungarian Vizsla dog which had never been abroad was referred with poor general condition, decrease in body weight, haematemesis and jaundice to the Central Clinic of Veterinary Science University, Budapest. After symptomatic treatment abdominal ultrasonography and diagnostic laparatomy were carried out. The dog was humanely euthanized two days later following owner's consent because of sudden worsening of clinical conditions. Two adult heartworms (Dirofilaria immitis) were found in the right ventricle partially coiling around the tricuspid valve. PCR on blood was positive for both $D$. immitis and Dirofilaria repens while only D. repens microfilariae were found by modified Knott's test and the serological test was negative for $D$. immitis antigens. This is the first, confirmed report of autochthonous canine heartworm infection in Hungary.
\end{abstract}

Keywords: Dirofilaria immitis, Dirofilaria repens, dirofilariosis, dog, Hungary

\section{Introduction}

A growing number of arthropod-borne diseases have been observed during in recent years in Hungary as a consequence of climatic changes, including Dirofilaria repens (Filarioidea, Onchocercidae), a mosquito-borne, zoonotic infection of domestic and wild carnivores transmitted by Culicidae (Fok et al., 1998; Széll et al., 1999; Genchi et al., 2007). The veterinary importance of Dirofilaria immitis (heartworm) is definitely greater as this parasite lives in the right cardiac chambers and pulmonary vessels of dog and cats and can cause fatal disease (Vörös et al., 2000; Genchi et al., 2007; Venco et al., 2008).

Heartworm infection in dogs is present worldwide and is endemic in several European countries, particularly Italy (Genchi et al., 2007). Recently, dogs infected with $D$. immitis have been found in Croatia, Serbia, Bulgaria, Ro- mania and Slovakia and seropositivity has been detected in Czech Republic (Svobodova et al., 2005; Genchi et al., 2005; Genchi et al., 2007; Miterpáková et al., 2008). So far, only imported cases have been reported from Hungary (Boros et al., 1982; Vörös et al., 2000).

\section{Material and Methods}

In September 2007 a 4-year-old, male Hungarian Vizsla dog was referred to the Central Clinic of the Faculty of Veterinary Science in Budapest. The dog was from a local breeder from one of the eastern counties, namely JászNagykun-Szolnok. Its parents lived in the same area and were used as hunting dogs. The father had frequent contact with dogs from Italy, brought into this area by Italian hunters. The puppy moved to its owner's home at 10 weeks of age, remained in the same county and never travelled abroad. Earlier the owner observed polydipsia and exercise intolerance. The dog was referred to the Clinic with several days' history of haematemesis, decrease in body weight and jaundice. After symptomatic treatment abdominal ultrasonography and diagnostic laparatomy were carried out. Modified Knott's test for circulating microfilariae and serology for circulating female antigens (Speed ${ }^{\circledR}$ DIRO, BVT, La Seyne Sur Mer, France) were carried out. For the modified Knott's method 4 drops of saponine solution and $5 \mathrm{ml}$ of distillate water were given to the $1 \mathrm{ml}$ EDTA blood and it was stained with Nile blue; after centrifugation the larvae were checked from the bottom of the prepared sample using light microscope. In order to screen for the presumably low-numbered microfilariae of $D$. immitis in the blood sample, molecular techniques were used. DNA extraction was performed from $100 \mu \mathrm{L}$ of EDTA blood by DNeasy blood and tissue kit (QIAGEN). At first a $12 \mathrm{~S}$ general filarioid primer using PCR was applied amplifying DNA fragments from all of the filarioid worms. PCR products were loaded on $1.5 \%$ agarose gel. The amplicons 
were then gel purified (QIAquick gel extraction kit, QIAGEN), and directly sequenced using ABI technology. Species-specific PCR reactions were carried out to detect both $D$. repens and $D$. immitis microfilariae, during which process $12 \mathrm{~S}$ general reverse and species-specific forward primers were used as described by Casiraghi et al., 2006. Two days later after admitting the dog was humanely euthanized following the owner's request, due to the rapid worsening of clinical conditions and necropsy performed.

\section{Results}

The physical examination of the dog showed severe icterus and anaemia, extended capillar refill time and Kussmaultype dyspnoe. During the abdominal ultrasonography enlarged liver with increased intensity, and excessive intensity of the cortex of the kidney were detected. Severe anaemia, high leukocyte number, thrombocytopenia, hypoproteinaemia, definitely high level of liver enzymes, lipase, urea and creatinin were found by the blood testing. The diagnostic laparatomy resulted in finding coagulated blood in the cavity of the stomach. In accordance with the symptoms severe anaemia and jaundice were seen on the body of the dog during the dissection. The examination showed hyperaemia of the organs. There were necrotic lesions in the liver and grey-whitish nodules in the cortex of the kidneys. On the pyloric part of the duodenum deep mucosal ulcer was detected, which reached the submucosal region and resulted in considerable bleeding into the lumen of the intestines and the stomach. The right heart was dilated and two slowly moving worms of yellow-whitish colour were located inside (Fig. 1).

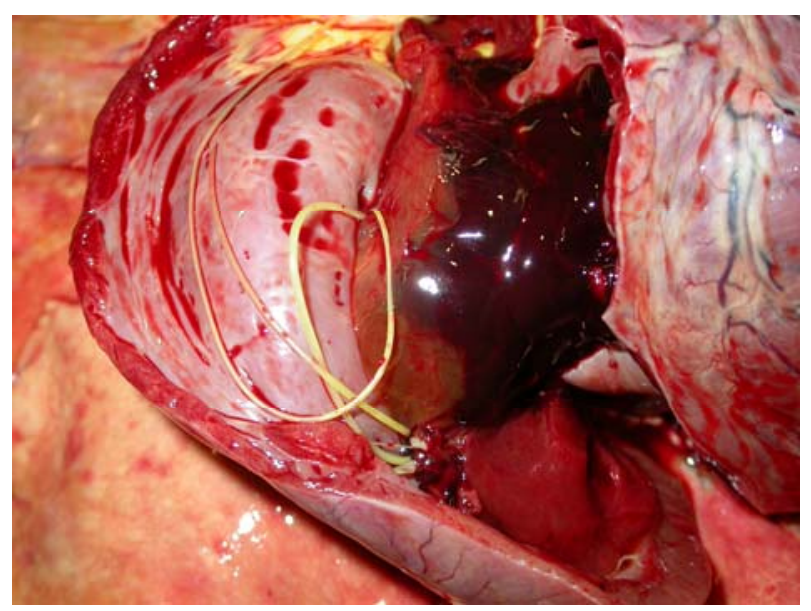

Fig. 1. Dirofilaria immitis worms in the heart

Two D. immitis adult specimens were found in the right cardiac ventricle, one male worm (131 mm in length; spirally coiled tail) and one female worm (236 mm in length; the proximal and middle part of the uterus containing immature embryos and microfilariae). The ventricle was enlarged and the worms were partially coiled around the tricuspid valve (Photograph). Numerous hooked-tailed, $390 \mu \mathrm{m}$-long microfilariae identified as D. repens microfilaria were found in the examined blood sample. No $D$. immitis microfilariae were observed and the serological test was negative for $D$. immitis antigens. In order to identify the species of microfilariae in the sample several molecular methods were used. However, a species-specific PCR-based exam (Casiraghi et al., 2006) carried out on the blood confirmed the presence of both $D$. repens and $D$. immitis microfilariae, these latter probably in a too low number to be evidenced by Knott test. It is likely that heartworm infection was not the primary cause of the dog's condition, considering that other pathological lesions were found (necrotic lesions in the liver, grey-whitish nodules in the kidney cortex and deep mucosal ulcers on the pyloric part of the duodenum). Nevertheless, we cannot exclude that the infection had played a role in the condition taking into account that heartworms were coiling the tricuspid valve.

\section{Discussion}

This is the first autochthonous case of canine heartworm infection reported from Hungary, confirming the evidence of the spreading of dirofilarial parasites from the Mediterranean areas to eastern countries of Europe. Previous studies have shown a $D$. repens prevalence of $14 \%$ in dogs living in Hungary (Fok et al., 2007), with the infection risk extending from June to October, based on analysis of climatic predictions for extrinsic incubation of Dirofilaria (Genchi et al., 2005; Genchi et al., 2007). We may hypothesize that hunting dogs from Italy with patent heartworm infection acted as microfilarial reservoirs for the local mosquito population during their stay in the area, resulting in the development and the transmission of infective larvae to native dogs.

Supposedly this infection is somewhat more common among Hungarian dogs, but as pointed out in the case described above it is rather difficult to confirm the presence of D. immitis by basic clinical or routine laboratory examinations. The sometimes moderate symptoms caused by just few worms can easily be neglected, moreover, the possibility of co-infection by $D$. repens can add further difficulty to make an exact diagnosis. And the rapid tests available for practitioners cannot always detect heartworm infection, because the sensitivity of these kits is sometimes insufficient. According to the homepage of the American Heartworm Society it takes only one, while based on Italian sources it takes at least two adult female worms to have positive results (Genchi et al., 2007), making the diagnosis of doubtful cases with moderate symptoms even more complicated.

This report calls the attention not only to Hungarian veterinarians about the need of monitoring the infection in the area, but also of medical doctors because of the zoonotic importance of D. immitis.

\section{Acknowledgements}

We are grateful to István Nagy Hinst, the owner of the dog to present detailed information. 


\section{References}

OFFICIAL HOMEPAGE OF AMERICAN HEARTWORM SOCIETY. (2005): http://www.heartwormsociety.org/canine heartworminfo.htm

Boros, G., JANisch, M., SeBestyén, Gy. (1982): Dirofilaria immitis fertőzöttség kutyában [Dirofilaria immitis infestation in dogs]. Hungar. Vet. J., 37: 313 - 316

Casiraghi, M., Bazzocchi, C., Mortarino, M., Ottina, E., GENCHI, C. (2006): A simple molecular method for discriminating common filarial nematodes of dogs (Canis familiaris). Vet. Parasitol., 141: 368 - 372

FOK, É., SZABÓ, Z., FARKAS, R. (1998): Dirofilaria repens első hazai diagnosztizálása kutyában sebészeti beavatkozás során [The first autochthonous case of a dog infected with Dirofilaria repens in Hungary]. Kisállatorvoslás, 4: 218 219

FoK, É., Kiss, G., Majoros, G., Jacsó, O., FARKas, R., GYUROVSZKY, M. (2007): Preliminary results of an epidemiological survey on dirofilariosis of dog and cat in Hungary. In GenchI, C., Rinaldi, L., CRINGOli, G. (Eds.): Mappe parassitologiche 8. Rolando Editore, Naples pp.195 Genchi, C., Rinaldi, L., Cascone, C., Mortarino, M., CRINGOLI, C. (2005): Is heartworm disease really spreading in Europe? Vet. Parasitol., 113: 137 - 148
Genchi, C., Rinaldi, L., CRINGOLI, G. (2007): Dirofilaria immitis and Dirofilaria repens in dog and cat and human infections. In GenCHI, C., RinAldi, L., CRINGOLI, G. (Eds.): Mappe parassitologiche 8. Rolando Editore, Naples pp. 211

MiterpákovÁ, M., Antolová, D., Hurníková, P., DUBINSKÝ, P. (2008): Dirofilariosis in Slovakia - a new endemic area in Central Europe. Helminthologia, 45: 20-23 Svobodová, V., Svobodová, Z., Beladičová, V., VALENTOVÁ, D. (2005): First cases of dirofilariosis in Slovakia: a case report. Vet. Med. - Czech, 50:510 - 512

Széll, Z., SRéter, T., CsiKós, K., KÁtai, Z., DobosKovÁCs, M., VetéSI, F., VARGA, I. (1999): Autochthon Dirofilaria repens fertőzöttség kutyákban [Autochthonous infection with Dirofilaria repens in dogs in Hungary]. Hungar. Vet. J., 121: $100-104$

Venco, L., Genchi, C., Genchi, M., Grandi, G., KRAMER, L. H. (2008): Clinical evaluation and radiographic findings of feline heartworm infection in asymptomatic cats. Vet Parasitol., 158: $232-237$

VÖRÖs, K., KIss, G., BAskA, F., BAGdi, N., SzÉll, Z. (2000): Irodalmi áttekintés és esetismertetés [Heartworm disease in dogs. Review article and case report]. Hungar. Vet. J., 122: $707-716$

ACCEPTED JUNE 12, 2009 